\title{
Usutu virus disease: a potential problem for North America?
}

\section{Christine M. Gill ${ }^{1}$ - Ronak K. Kapadia ${ }^{1}$ - J. David Beckham ${ }^{1}$ • Amanda L. Piquet ${ }^{1} \cdot$ Kenneth L. Tyler $^{1,2}$ • Daniel M. Pastula ${ }^{1,3}$ (1)}

Received: 7 September 2019/Revised: 7 September 2019 / Accepted: 18 November 2019 /Published online: 19 December 2019

(C) Journal of NeuroVirology, Inc. 2019

\begin{abstract}
Usutu virus is an emerging mosquito-borne flavivirus initially identified in South Africa in 1959 that is now circulating throughout parts of Africa, Europe, and the Middle East. It is closely related to West Nile virus, and has similar vectors, amplifying bird hosts, and epidemiology. Usutu virus infection can occur in humans and may be asymptomatic or cause systemic (e.g., fever, rash, and hepatitis) or neuroinvasive (e.g., meningitis and encephalitis) disease. Given few reported cases, the full clinical spectrum is not known. No anti-viral treatment is available, but it can be largely prevented by avoiding mosquito bites. Because of similar mosquitoes, birds, and climate to Europe, the potential for introduction to North America is possible.
\end{abstract}

Keywords Usutu $\cdot$ Usutu virus $\cdot$ Flavivirus $\cdot$ Flaviviridae $\cdot$ Arbovirus $\cdot$ Arboviral disease

\section{Virology and vectors}

Usutu virus is an emerging mosquito-borne flavivirus in family Flaviviridae (CDC 2018a Arbovirus Catalog). Similar to other flaviviruses, it is a small $(40-60 \mathrm{~nm})$, spherical, enveloped, positive-sense ribonucleic acid (RNA) virus (Bakonyi et al. 2004). Classified within the Japanese encephalitis virus serogroup, Usutu virus is closely related to Murray Valley encephalitis, Japanese encephalitis, West Nile, and St. Louis encephalitis viruses (Bakonyi et al. 2004; Poidinger et al. 1996).

Culex pipiens appears to be the primary vector for Usutu virus transmission, at least in Europe (Calzolari et al. 2012; Engler et al. 2013; Fros et al. 2015). However, Usutu virus has also been found in other Culex and certain Aedes, Anopheles, Coquillettidia, Culiseta, Mansonia, and Ochlerotatus

Daniel M. Pastula

Daniel.Pastula@cuanschutz.edu

1 Neuro-Infectious Diseases Group, Department of Neurology and Division of Infectious Diseases, University of Colorado School of Medicine, Mail Stop B182, Research Complex 2, 12700 East 19th Ave., Anschutz Medical Campus, Aurora, CO 80045, USA

2 Department of Immunology-Microbiology, University of Colorado School of Medicine, Aurora, CO, USA

3 Department of Epidemiology, Colorado School of Public Health, Aurora, CO, USA mosquito species (Ashraf et al. 2015; Camp et al. 2019, Engler et al. 2013; Mannasse et al. 2017; Nikolay et al. 2011), though these species' potential roles in transmission is not known. Interestingly, experimental data suggest Culex pipiens and Culex quinquefasciatus (but not Aedes albopictus) may be competent vectors for potential future Usutu virus transmission in North America (Cook et al. 2018).

A wide variety of birds throughout Europe (e.g., blackbirds, doves, jays, magpies, partridges, owls, and sparrows) have been found to carry Usutu virus and may serve as the primary amplifying hosts for mosquito vectors (Ashraf et al. 2015; Calzolari et al. 2012; Chvala et al. 2007; Nikolay 2015). Many of the same or related bird species that likely serve as Usutu virus amplifying hosts in Europe are also found in North America.

Usutu virus has also been found to infect bats, rodents, and other mammals (Cadar et al. 2014; Diagne et al. 2019), but these may be primarily dead-end hosts (i.e., not capable of amplifying the virus and transmitting it other vectors) rather than amplifying hosts. Humans, when infected with Usutu virus (or similarly with West Nile virus), are also are thought to be incidentally infected dead-end hosts.

Usutu virus has been found to co-circulate with West Nile virus in parts of Europe (Cabanova et al. 2019; Nikolay 2015), and one asymptomatic blood donor in Austria was found to be potentially co-infected acutely with both viruses (Aberle et al. 2018). This co-circulation is not surprising given the two closely related viruses share common amplifying hosts 
(various bird species) and vectors (primarily Culex spp. of mosquitoes). Similar co-circulation between West Nile virus and the closely related St. Louis encephalitis virus has been described in North America (Venkat et al. 2015).

\section{Epidemiology and geographic distribution}

Usutu virus was first isolated from Culex neavei mosquitoes near the Usutu river in Natal, South Africa, in 1959 (McIntosh 1985; Williams et al. 1964), although it is suspected that Usutu virus emerged in Africa approximately 500 years ago and gradually spread throughout parts of the continent (Engel et al. 2016; Nikolay et al. 2011). The first report of Usutu virus emergence in Europe occurred in 2001 during a widespread bird die-off in Austria (Weissenbock et al. 2002). Analysis of dead bird tissue (from blackbirds, owls, and a swallow) revealed the presence of Usutu virus, and it was initially thought that this represented the first emergence of Usutu virus in Europe. A later retrospective investigation found that Usutu virus was present in tissue samples from Eurasian blackbirds who died during a similar bird die-off in 1996 in Tuscany, Italy, suggesting that Usutu virus was circulating in parts of Europe by 1996 or earlier (Weissenbock et al. 2013).

Usutu virus (or nucleic acid) has since been detected in mosquitoes, birds, or bats in several other European countries including Belgium (Garigliany et al. 2014), France (Lecollinet et al. 2016), Germany (Cadar et al. 2014; Engler et al. 2013; Michel et al. 2019), Hungary (Bakonyi et al. 2007), Slovakia (Cabanova et al. 2019), Spain (Busquets et al. 2008; Engler et al. 2013; Vazquez et al. 2011), and Switzerland (Engler et al. 2013; Steinmetz et al. 2011). Usutu virus has also been detected in mosquitoes in Israel (Mannasse et al. 2017), as well as in mosquitoes or animals in the African countries of Central African Republic, Cote d'Ivoire, Senegal, Nigeria, and Uganda (Diagne et al. 2019; Nikolay et al. 2011). Usutu virus neutralizing antibodies have been found in various animals in other European and African countries (Ashraf et al. 2015; Nikolay et al. 2011; Nikolay 2015), but it is not clear in all cases whether the antibodies produced were against a different infecting flavivirus or, if from Usutu virus infection, where the virus was actually acquired. Regardless, all of this data provides evidence for current or prior Usutu virus circulation throughout parts of Africa, the Middle East, and Europe.

Humans in parts of African and Europe have also been infected with Usutu virus. Usutu virus or nucleic acid has been isolated from symptomatic residents of Burkina Faso (Nikolay et al. 2011), Central African Republic (Nikolay et al. 2011), and more recently France (Simonin et al. 2018) and Italy (Cavrini et al. 2009; Grottola et al. 2017; Pecorari et al. 2009). Usutu virus nucleic acid has also been recently isolated from asymptomatic blood donors in Austria (Aberle et al. 2018; Bakonyi et al. 2017), Germany (Cadar et al. 2017), and the Netherlands (Zaaijer et al. 2019). Additionally, Usutu virus neutralizing antibodies have recently been found in symptomatic residents of Croatia (Santini et al. 2015) and asymptomatic residents (including blood donors) of Germany (Allering et al. 2012) and Italy (Gaibani et al. 2012; Grottola et al. 2017; Percivalle et al. 2017; Pierro et al. 2013).

As Usutu virus infection is likely under-recognized, the full incidence, geographic distribution, and seasonality is yet to be determined (though one might expect more cases occurring in warmer months when other mosquito-borne arboviral diseases tend to occur). Given so few Usutu virus disease cases have been reported in the literature, it is currently difficult to determine any potential age, gender, or other demographic predilections (though most age groups and both sexes have been affected). This may change with future reports of infections.

\section{Clinical presentation and disease}

The asymptomatic rate of Usutu virus infection in humans is not yet known, but asymptomatic infections do occur as evidenced by reports of acutely viremic asymptomatic blood donors (Aberle et al. 2018; Bakonyi et al. 2017; Zaaijer et al. 2019). Based on limited case reports or case series, for those infected who develop symptoms, Usutu virus disease appears to manifest with a systemic or neuroinvasive syndrome.

Systemically, acute infection with Usutu virus has been reported to cause a fever with rash and a fever with jaundice (Nikolay et al. 2011). A transient rash was also described in a blood donor positive for Usutu virus nucleic acid (Aberle et al. 2018). One complicated systemic case involved a woman in her 40s who developed thrombotic thrombocytopenic purpura requiring multiple plasma exchanges followed by fever, rash, and fulminant hepatitis with coma eventually requiring liver transplantation. While she regained consciousness after transplantation, her final outcome was not reported. Her pretransplant serum sample was later found to be positive for Usutu virus nucleic acid. It is not known when or how she acquired Usutu virus infection, or how it may have contributed to her complex disease course (Cavrini et al. 2009).

Usutu virus infection also appears capable of causing neurologic disease. In laboratory experiments, Usutu virus has been shown to infect mature neurons, human neuronal precursors, microglia and primary human astrocytes (Salinas et al. 2017). It has also been shown to cause neuronal death and demyelination in mice (Weissenbock et al. 2004).

One of the first reported cases of Usutu virus neuroinvasive disease was in an older woman with diffuse large B cell lymphoma on chemotherapy who presented with fever, resting tremor, and anemia requiring blood transfusion (Pecorari et al. 2009). MRI of the brain showed lesions in her substantia nigra and subcortex. Cerebrospinal fluid (CSF) analysis was reportedly unremarkable, but both the serum and CSF were 
positive for Usutu virus nucleic acid. She was treated with a course of steroids. Her fever resolved, but her resting tremor remained.

A retrospective analysis on banked CSF samples in Italy from between 2008 and 2011 identified 8 acute Usutu virus neuroinvasive infections among those with various chronic diseases; four had limited clinical descriptions (two cases of meningoencephalitis, one of encephalitis, and one of encephalitis and polyneuritis) (Grottola et al. 2017).

In 2013, three cases of meningoencephalitis (with headache, fever, nuchal rigidity, hand tremor, and/or hyperreflexia) diagnosed as Usutu virus infection on the basis of serologic testing were reported from Croatia (Santini et al. 2015). All had a CSF pleocytosis with elevated protein and normal glucose. Recovery was partial in one and complete in two.

Additional case reports of Usutu virus neuroinvasive disease among healthy adults include an uncomplicated meningitis case that presented with fever, headache, and nuchal rigidity (Nagy et al. 2019) and an acute facial palsy with ptosis, dysgeusia, and unilateral paresthesias (Simonin et al. 2018). Both recovered fully after a few weeks.

Given the limited number of case reports, the possible clinical syndromes, morbidity, and potential mortality of Usutu virus disease are not yet known. More studies are needed to better define its full clinical spectrum.

\section{Diagnosis and testing}

Similar to other arboviral infections, the diagnosis of Usutu virus infection can be confirmed by viral isolation in culture or detection of viral nucleic acid in serum and/or CSF by reverse transcription-polymerase chain reaction (CDC 2015 Arboviral Diseases). Viremia, however, may not be sufficiently high and persistent enough for detection by culture or molecular methods. Serologic testing of serum and/or CSF for antibodies, despite being fraught with potential cross-reactivity and IgM persistence problems, may instead be required for diagnosis. A positive viral-specific immunoglobulin (Ig) M test followed by a confirmatory neutralizing antibody test (e.g., plaque reduction neutralization tests or PRNTs) or a fourfold or greater change in neutralizing antibody titers between acute and convalescent samples are both considered confirmatory for recent arboviral infection (CDC 2015 Arboviral Diseases). Serologic testing results must be interpreted carefully, however, given significant potential cross-reactivity between the Usutu and West Nile virus IgM and even neutralizing antibody tests (CDC 2015 Arboviral Diseases; Llorente et al. 2019).

No commercial Usutu virus tests exist at this time, though some public health reference laboratories may be able to perform testing. Health care providers should contact their local or state health department for assistance with Usutu virus testing.

\section{Treatment and prevention}

Similar to West Nile virus disease (CDC 2018a, b West Nile virus), there are no proven human anti-viral treatments for Usutu virus disease at this time, though favipiravir (a viral RNA polymerase inhibitor) has shown some efficacy in mice (Segura Guerrero et al. 2018). Current management is largely supportive and may include intravenous fluids, anti-pyretic medications, anti-nausea medications, pain control, and/or clinical observation. Patients who develop meningoencephalitis may need to be monitored for elevated intracranial pressure and/or seizures. Consultation with infectious disease and/or neurology specialists may be needed.

Usutu virus is likely primarily transmitted by mosquitoes; therefore, preventing mosquito bites is the best way to prevent Usutu virus disease. People should consider using insect repellent on exposed skin, wearing long-sleeved shirts and pants when feasible, and/or applying permethrin on clothing when spending time outdoors when mosquitoes are active (CDC 2018a, b West Nile virus). Using air conditioning or window screens while indoors will help keep mosquitoes outside. Standing water should be periodically dumped from containers around homes and businesses as well.

There is also a potential risk of Usutu virus transmission through blood transfusion (and possibly organ transplantation by extension) given reports of viremic blood donors (Aberle et al. 2018; Bakonyi et al. 2017; Cadar et al. 2017; Domanovic et al. 2019; Zaaijer et al. 2019), though the exact risk is not known. Blood donors in endemic areas who have been recently sick with a clinical illness compatible with an arboviral disease may want to delay blood donation. Blood donation agencies and regulators may want to assess the risk for transmission in endemic areas and consider updating their testing protocols accordingly. Of note, there have been reports of blood donors with Usutu virus infections testing positive for screening West Nile virus nucleic acid tests (NAT), suggesting potential screening NAT cross-reactivity between these related viruses (Domanovic et al. 2019).

No human vaccine against Usutu virus is currently available, though an experimental DNA vaccine appeared to be protective in mice (Martín-Acebes et al. 2016). It is not known whether previous infection with a closely related flavivirus (e.g., West Nile virus) may protect humans against later infection with Usutu virus, though there is some evidence of partial post-flavivirus infection cross-protection in mice (Blazquez et al. 2015). 


\section{Summary and recommendations}

Usutu virus is a mosquito-borne flavivirus currently circulating in parts of Africa, Europe, and the Middle East. It has been reported to co-circulate with West Nile virus at times, and bears many similarities to West Nile virus in terms of virology, transmission, epidemiology, and clinical presentation. Several cases of Usutu virus disease, including neuroinvasive disease, have been reported from Europe and Africa. People in endemic areas should practice mosquito bite prevention, and physicians in endemic areas should consider Usutu virus infection on their differential of patients presenting with a potential arboviral disease.

Although Usutu virus has not been detected in North America, there is a risk of introduction and circulation given similar vectors, amplifying bird hosts, and climates to Europe. Public health surveillance authorities throughout North America should be aware of this possibility.

Funding information Dr. Piquet has received research funding from the Drake Family and the Rocky Mountain MS Center, honoraria from MedLink, and consulting fees from Sanofi Genzyme and Genentech, though none of these organizations sponsored this research.

\section{Compliance with ethical standards}

Conflict of interest Drs. Gill, Kapadia, Beckham, Tyler, and Pastula have no conflicts of interest.

\section{References}

Aberle SW, Kolodziejek J, Jungbauer C, Stiasny K, Aberle JH, Zoufaly A, Hourfar MK, Weidner L, Nowotny N (2018) Increase in human West Nile and Usutu virus infections, Austria, 2018. Euro Surveill 23(43). https://doi.org/10.2807/1560-7917.ES.2018.23.43.1800545

Allering L, Jost H, Emmerich P, Gunther S, Lattwein E, Schmidt M, Seifried E, Sambri V, Hourfar K, Schmidt-Chanasit J (2012) Detection of Usutu virus infection in a healthy blood donor from south-west Germany, 2012. Euro Surveill;17(50). pii: 20341

Ashraf U, Ye J, Ruan X, Wan S, Zhu B, Cao S (2015) Usutu virus: an emerging flavivirus in Europe. Viruses 7(1):219-238. https://doi. org/10.3390/v7010219

Bakonyi T, Gould EA, Kolodziejek J, Weissenbock H, Nowotny N (2004) Complete genome analysis and molecular characterization of Usutu virus that emerged in Austria in 2001: comparison with the south African strain SAAR-1776 and other flaviviruses. Virology 328(2):301-310. https://doi.org/ 10.1016/j.virol.2004.08.005

Bakonyi T, Erdelyi K, Ursu K, Ferenczi E, Csorgo T, Lussy H, Chvala S, Bukovsky C, Meister T, Weissenbock H, Nowotny N (2007) Emergence of Usutu virus in Hungary. J Clin Microbiol 45(12): 3870-3874. https://doi.org/10.1128/JCM.01390-07

Bakonyi T, Jungbauer C, Aberle SW, Kolodziejek J, Dimmel K, Stiasny K, Allerberger F, Nowotny N (2017) Usutu virus infections among blood donors, Austria, July and August 2017 - raising awareness for diagnostic challenges. Euro Surveill 22(41). https://doi.org/10.2807/ $1560-7917$
Blázquez AB, Escribano-Romero E, Martín-Acebes MA, Petrovic T, Saiz JC (2015) Limited susceptibility of mice to Usutu virus (USUV) infection and induction of flavivirus cross-protective immunity. Virology 482:67-71. https://doi.org/10.1016/j.virol.2015.03.020

Busquets N, Alba A, Allepuz A, Aranda C, Ignacio Nunez J (2008) Usutu virus sequences in Culex pipiens (Diptera: Culicidae), Spain. Emerg Infect Dis 14(5):861-863. https://doi.org/10.3201/eid1405.071577

Cabanova V, Sikutova S, Strakova P, Sebesta O, Vichova B, Zubrikova D, Miterpakova M, Mendel J, Hurnikova Z, Hubalek Z, Rudolf I (2019) Co-circulation of West Nile and Usutu flaviviruses in mosquitoes in Slovakia, 2018. Viruses 11(7). Pii: E639. https://doi.org/ 10.3390/v11070639

Cadar D, Becker N, Campos Rde M, Börstler J, Jöst H, Schmidt-Chanasit J (2014) Usutu virus in bats, Germany, 2013. Emerg Infect Dis 20(10):1771-1773. https://doi.org/10.3201/eid2010.140909

Cadar D, Maier P, Müller S, Kress J, Chudy M, Bialonski A, Schlaphof A, Jansen S, Jöst H, Tannich E, Runkel S, Hitzler WE, Hutschenreuter G, Wessiepe M, Schmidt-Chanasit J (2017). Blood donor screening for West Nile virus (WNV) revealed acute Usutu virus (USUV) infection, Germany, September 2016. Euro Surveill. 22(14). pii: 30501. doi: https://doi.org/10.2807/1560-7917.ES. 2017.22.14.30501

Calzolari M, Gaibani P, Bellini R, Defilippo F, Pierro A, Albieri A, Maioli G, Luppi A, Rossini G, Balzani A, Tamba M, Galletti G, Gelati A, Carrieri M, Poglayen G, Cavrini F, Natalini S, Dottori M, Sambri V, Angelini P, Bonilauri P (2012) Mosquito, bird and human surveillance of West Nile and Usutu viruses in Emilia-Romagna Region (Italy) in 2010. PLoS One 7(5):e38058. https://doi.org/10.1371/ journal.pone. 0038058

Camp JV, Kolodziejek J, Nowotny N (2019) Targeted surveillance reveals native and invasive mosquito species infected with Usutu virus. Parasit Vectors 12(1):46. https://doi.org/10.1186/s13071-0193316-Z

Cavrini F, Gaibani P, Longo G, Pierro AM, Rossini G, Bonilauri P, Gerunda GE, Di Benedetto F, Pasetto A, Girardis M, Dottori M, Landini MP, Sambri V (2009) Usutu virus infection in a patient who underwent orthotropic liver transplantation, Italy, AugustSeptember 2009. Euro Surveill 14(50). pii: 19448

CDC (2015) Arboviral diseases, neuroinvasive and non-neuroinvasive. Available via: https://wwwn.cdc.gov/nndss/conditions/arboviraldiseases-neuroinvasive-and-non-neuroinvasive/case-definition/ 2015/ [Accessed June 1, 2019]

CDC (2018a) Arbovirus catalog. Centers for Disease Control and Prevention. Available via: https://wwwn.cdc.gov/arbocat/. Accessed 1 June 2019

CDC (2018b) West Nile virus. Centers for Disease Control and Prevention. Available via: https://www.cdc.gov/westnile/index. html. Accessed 1 June 2019

Chvala S, Bakonyi T, Bukovsky C, Meister T, Brugger K, Rubel F, Nowotny N, Weissenböck H (2007) Monitoring of Usutu virus activity and spread by using dead bird surveillance in Austria, 20032005. Vet Microbiol 122(3-4):237-245. https://doi.org/10.1016/j. vetmic.2007.01.029

Cook CL, Huang YJS, Lyons AC, Alto BW, Unlu I, Higgs S, Vanlandingham DL (2018) North American Culex pipiens and Culex quinquefasciatus are competent vectors for Usutu virus. PLoS Negl Trop Dis 12(8):e0006732. https://doi.org/10.1371/ journal.pntd.0006732

Diagne MM, Ndione MHD, Di Paola N, Fall G, Bedekelabou AP, Sembene PM, Faye O, Zanotto PMA, Sall AA (2019) Usutu virus isolated from rodents in Senegal. Viruses 11(2). pii: E181. doi: https://doi.org/10.3390/v11020181

Domanovic D, Gossner CM, Lieshout-Krikke R, Mayr W, Baroti-Toth K, Dobrota AM, Escoval MA, Henseler O, Jungbauer C, Liumbruno G, Oyonarte S, Politis C, Sandid I, Vidovic MS, Young JJ, UshiroLumb I, Nowotny N (2019) West Nile and Usutu virus infections 
and challenges to blood safety in the European Union. Emerg Infect Dis 25(6):1050-1057. https://doi.org/10.3201/eid2506.181755

Engel D, Jost H, Wink M, Borstler J, Bosch S, Garigliany MM, Jost A, Czajka C, Luhken R, Ziegler U, Groschup MH, Pfeffer M, Becker N, Cadar D, Schmidt-Chanasit J (2016) Reconstruction of the evolutionary history and dispersal of Usutu virus, a neglected emerging arbovirus in Europe and Africa. MBio 7(1):e01938-e01915. https:// doi.org/10.1128/mBio.01938-15

Engler O, Savini G, Papa A, Figuerola J, Groschup MH, Kampen H, Medlock J, Vaux A, Wilson AJ, Werner D, Jöst H, Goffredo M, Capelli G, Federici V, Tonolla M, Patocchi N, Flacio E, Portmann J, Rossi-Pedruzzi A, Mourelatos S, Ruiz S, Vázquez A, Calzolari M, Bonilauri P, Dottori M, Schaffner F, Mathis A, Johnson N (2013) European surveillance for West Nile virus in mosquito populations. Int J Environ Res Public Health 10(10):4869-4895. https://doi.org/ 10.3390/ijerph10104869

Fros JJ, Miesen P, Vogels CB, Gaibani P, Sambri V, Martina BE, Koenraadt CJ, van Rij RP, Vlak JM, Takken W, Pijlman GP (2015) Comparative Usutu and West Nile virus transmission potential by local Culex pipiens mosquitoes in north-western Europe. One Health 1:31-36. https://doi.org/10.1016/j.onehlt.2015.08.002

Gaibani P, Pierro A, Alicino R, Rossini G, Cavrini F, Landini MP, Sambri V (2012) Detection of Usutu-virus-specific IgG in blood donors from northern Italy. Vector Borne Zoonotic Dis 12(5):431-433. https://doi.org/10.1089/vbz.2011.0813

Garigliany MM, Marlier D, Tenner-Racz K, Eiden M, Cassart D, Gandar F, Beer M, Schmidt-Chanasit J, Desmecht D (2014) Detection of Usutu virus in a bullfinch (Pyrrhula pyrrhula) and a great spotted woodpecker (Dendrocopos major) in north-west Europe. Vet $\mathrm{J}$ 199(1):191-193. https://doi.org/10.1016/j.tvj1.2013.10.017

Grottola A, Marcacci M, Tagliazucchi S, Gennari W, Di Gennaro A, Orsini M, Monaco F, Marchegiano P, Marini V, Meacci M, Rumpianesi F, Lorusso A, Pecorari M, Savini G (2017) Usutu virus infections in humans: a retrospective analysis in the municipality of Modena, Italy. Clin Microbiol Infect 23(1):33-37. https://doi.org/ 10.1016/j.cmi.2016.09.019

Lecollinet S, Blanchard Y, Manson C, Lowenski S, Laloy E, Quenault H, Touzain F, Lucas P, Eraud C, Bahuon C, Zientara S, Beck C, Decors A (2016) Dual emergence of Usutu virus in common blackbirds, eastern France, 2015. Emerg Infect Dis 22(12):2225. https://doi. org/10.3201/eid2212.161272

Llorente F, Garcia-Irazabal A, Perez-Ramirez E, Cano-Gomez C, Sarasa M, Vazquez A, Jimenez-Clavero MA $(2019,2019)$ Influence of flavivirus co-circulation in serological diagnostics and surveillance: a model of study using West Nile, Usutu and Bagaza viruses. Transbound Emerg Dis. https://doi.org/10.1111/tbed.13262

Mannasse B, Mendelson E, Orshan L, Mor O, Shalom U, Yeger T, Lustig Y (2017) Usutu Virus RNA in Mosquitoes, Israel, 2014-2015. Emerg Infect Dis 23(10):1699-1702. https://doi.org/10.3201/ eid2310.171017

Martín-Acebes MA, Blázquez AB, Cañas-Arranz R, Vázquez-Calvo Á, Merino-Ramos T, Escribano-Romero E, Sobrino F, Saiz JC (2016) A recombinant DNA vaccine protects mice deficient in the alpha/ beta interferon receptor against lethal challenge with Usutu virus. Vaccine 34(18):2066-2073. https://doi.org/10.1016/j.vaccine.2016. 03.015

McIntosh BM (1985) Usutu (SAAr 1776), nouvel arbovirus du groupe B. Int Cat Arboviruses 3:1059-1060

Michel F, Sieg M, Fischer D, Keller M, Eiden M, Reuschel M, Schmidt V, Schwehn R, Rinder M, Urbaniak S, Muller K, Schmoock M, Luhken R, Wysocki P, Fast C, Lierz M, Korbel R, Vahlenkamp TW, Groschup MH and Ziegler U (2019) Evidence for West Nile virus and Usutu virus infections in wild and resident birds in Germany, 2017 and 2018. Viruses 11(7). pii: E674. doi: https:// doi.org/10.3390/v11070674
Nagy A, Mezei E, Nagy O, Bakonyi T, Csonka N, Kaposi M, Koroknai A, Szomor K, Rigo Z, Molnar Z, Danielisz A, Takacs M (2019) Extraordinary increase in West Nile virus cases and first confirmed human Usutu virus infection in Hungary, 2018. Euro Surveill 24(28). https://doi.org/10.2807/1560-7917.ES.2019.24.28.1900038

Nikolay B, Diallo M, Boye CS, Sall AA (2011) Usutu virus in Africa. Vector Borne Zoonotic Dis 11(11):1417-1423. https://doi.org/10. 1089/vbz.2011.0631

Nikolay B (2015) A review of West Nile and Usutu virus co-circulation in Europe: how much do transmission cycles overlap? Trans R Soc Trop Med Hyg 109(10):609-618. https://doi.org/10.1093/trstmh/trv066

Pecorari M, Longo G, Gennari W, Grottola A, Sabbatini A, Tagliazucchi S, Savini G, Monaco F, Simone M, Lelli R, Rumpianesi F (2009) First human case of Usutu virus neuroinvasive infection, Italy, August-September 2009. Euro Surveill 14(50). pii: 19446

Percivalle E, Sassera D, Rovida F, Isernia P, Fabbi M, Baldanti F, Marone P (2017) Usutu virus antibodies in blood donors and healthy forestry workers in the Lombardy Region, Northern Italy. Vector Borne Zoonotic Dis 17(9):658-661. https://doi.org/10.1089/vbz.2017.2126

Pierro A, Gaibani P, Spadafora C, Ruggeri D, Randi V, Parenti S, Finarelli AC, Rossini G, Landini MP, Sambri V (2013) Detection of specific antibodies against West Nile and Usutu viruses in healthy blood donors in northern Italy, 2010-2011. Clin Microbiol Infect 19(10): E451-E453. https://doi.org/10.1111/1469-0691.12241

Poidinger M, Hall RA, Mackenzie JS (1996) Molecular characterization of the Japanese encephalitis serocomplex of the flavivirus genus. Virology 218(2):417-421. https://doi.org/10.1006/viro.1996.0213

Salinas S, Constant O, Desmetz C, Barthelemy J, Lemaitre JM, Milhavet O, Nagot N, Foulongne V, Perrin FE, Saiz JC, Lecollinet S, Van de Perre P, Simonin Y (2017) Deleterious effect of Usutu virus on human neural cells. PLoS Negl Trop Dis 11(9):e0005913. https:// doi.org/10.1371/journal.pntd.0005913

Santini M, Vilibic-Cavlek T, Barsic B, Barbic L, Savic V, Stevanovic V, Listes E, Di Gennaro A, Savini G (2015) First cases of human Usutu virus neuroinvasive infection in Croatia, August-September 2013: clinical and laboratory features. J Neuro-Oncol 21(1):92-97. https:// doi.org/10.1007/s13365-014-0300-4

Segura Guerrero NA, Sharma S, Neyts J, Kaptein SJF (2018) Favipiravir inhibits in vitro Usutu virus replication and delays disease progression in an infection model in mice. Antivir Res 160:137-142. https://doi.org/10.1016/j.antiviral.2018.10.026

Simonin Y, Sillam O, Carles MJ, Gutierrez S, Gil P, Constant O, Martin MF, Girard G, Van de Perre P, Salinas S, Leparc-Goffart I, Foulongne V (2018) Human Usutu virus infection with atypical neurologic presentation, Montpellier, France, 2016. Emerg Infect Dis 24(5):875-878. https://doi.org/10.3201/eid2405.171122

Steinmetz HW, Bakonyi T, Weissenbock H, Hatt JM, Eulenberger U, Robert N, Hoop R, Nowotny N (2011) Emergence and establishment of Usutu virus infection in wild and captive avian species in and around Zurich, Switzerland-genomic and pathologic comparison to other central European outbreaks. Vet Microbiol 148(2-4): 207-212. https://doi.org/10.1016/j.vetmic.2010.09.018

Vazquez A, Ruiz S, Herrero L, Moreno J, Molero F, Magallanes A, Sánchez-Seco MP, Figuerola J, Tenorio A (2011) West Nile and Usutu viruses in mosquitoes in Spain, 2008-2009. Am J Trop Med Hyg 85:178-181. https://doi.org/10.4269/ajtmh.2011.11-0042

Venkat H, Krow-Lucal E, Hennessey M, Jones J, Adams L, Fischer M, Sylvester T, Levy C, Smith K, Plante L, Komatsu K, Staples JE, Hills S (2015) Concurrent outbreaks of St. Louis encephalitis virus and West Nile virus disease - Arizona, 2015. MMWR Morb Mortal Wkly Rep 64(48):1349-1350. https://doi.org/10.15585/mmwr. mm6448a5

Weissenbock H, Bakonyi T, Chvala S, Nowotny N (2004) Experimental Usutu virus infection of suckling mice causes neuronal and glial cell apoptosis and demyelination. Acta Neuropathol 108(5):453-460. https://doi.org/10.1007/s00401-004-0916-1 
Weissenbock H, Kolodziejek J, Url A, Lussy H, Rebel-Bauder B, Nowotny N (2002) Emergence of Usutu virus, an African mosquito-borne flavivirus of the Japanese encephalitis virus group, Central Europe. Emerg Infect Dis 8(7):652-656. https://doi.org/10. 3201/eid0807.020094

Weissenbock H, Bakonyi T, Rossi G, Mani P, Nowotny N (2013) Usutu virus, Italy, 1996. Emerg Infect Dis 19(2):274-277. https://doi.org/ 10.3201/eid1902.121191

Williams MC, Simpson DI, Haddow AJ, Knight EM (1964) The isolation of West Nile virus from man and of Usutu virus from the bird-biting mosquito Mansonia Aurites (Theobald) in the Entebbe area of Uganda. Ann Trop Med Parasitol 58:367-374. https://doi.org/10. 1080/00034983.1964.11686258

Zaaijer HL, Slot E, Molier M, Reusken C, Koppelman M (2019) Usutu virus infection in Dutch blood donors. Transfusion. 2019. https:// doi.org/10.1111/trf.15444

Publisher's note Springer Nature remains neutral with regard to jurisdictional claims in published maps and institutional affiliations. 